\title{
Fusarium ear blight and the occurrence and harmfulness of fungi colonizing the grain of selected varieties of winter triticale (Triticale) grown in the organic system
}

\author{
Fuzarioza kłosów oraz występowanie i szkodliwość grzybów zasiedlających \\ ziarno wybranych odmian pszenżyta ozimego (Triticale) \\ uprawianego w systemie ekologicznym
}

\author{
Leszek Lenc ${ }^{1 *}$, Krzysztof Jończyk²
}

\section{Summary}

Triticale is an important feed component. Like other cereals, it can be infected by potentially mycotoxin-forming fungi of the Fusarium spp. In the years 2015-2017, the occurrence of fusariosis of ears and fungi colonizing winter triticale grain on selected cultivars cultivated in the organic system in two regions of the country was determined. Weather conditions during the flowering phase were not conducive to the infection by Fusarium spp., therefore, the symptoms were slight or trace. However, significant seed colonization by the pathogens was found. It varied depending on the year, cereal variety and location of the research. During the researched period in Grabów it averaged between 1.3 and $8.6 \%$ and in Tarasków between 2.1 and $13.0 \%$, but in individual years it reached up to $22.8 \%$. Fusarium avenaceum and Fusarium poae were most frequently isolated from grain.

Key words: organic farming, triticale, fungi, Fusarium spp.

\section{Streszczenie}

Pszenżyto jest ważnym komponentem pasz. Podobnie jak inne rośliny zbożowe, może być porażane przez grzyby potencjalnie mykotoksynotwórcze rodzaju Fusarium. W latach 2015-2017 określano występowanie fuzariozy kłosów i grzybów zasiedlających ziarno pszenżyta ozimego na wybranych odmianach uprawianych w systemie ekologicznym, w dwóch regionach kraju. Warunki pogodowe w fazie kwitnienia nie sprzyjały infekcji przez Fusarium spp., stąd objawy chorobowe były niewielkie bądź śladowe. Jednak stwierdzono znaczne zasiedlenie ziarna przez te patogeny. Było ono zróżnicowane w zależności od roku, odmiany i lokalizacji doświadczenia, średnio za okres badań wynosiło w Grabowie od 1,3 do 8,6\%, a w Taraskowie od 2,1 do 13,0\%, ale w poszczególnych latach dochodziło nawet do 22,8\%. Z ziarna najczęściej izolowano Fusarium avenaceum i Fusarium poae.

Słowa kluczowe: uprawa ekologiczna, pszenżyto, grzyby, Fusarium spp.

\footnotetext{
${ }^{1}$ Uniwersytet Technologiczno-Przyrodniczy im. Jana i Jędrzeja Śniadeckich w Bydgoszczy Kaliskiego 7, 85-796 Bydgoszcz

${ }^{2}$ Instytut Uprawy Nawożenia i Gleboznawstwa - Państwowy Instytut Badawczy

Czartoryskich 8, 24-100 Puławy

*corresponding author: lenc@utp.edu.pl

ORCID: 0000-0002-2017-8135
} 


\section{Wstęp / Introduction}

Coraz większe zainteresowanie żywnością ekologiczną wymaga znalezienia źródeł pasz odpowiadających wymogom ekologicznego żywienia zwierząt. Uprawa pszenżyta w Polsce ma duże znaczenie, szczególnie na glebach słabszych. Gatunek ten uprawiany na pasze ma duży potencjał plonotwórczy, ziarno dobrej jakości o wysokiej zawartości białka, korzystnym składzie aminokwasów i wysokim współczynniku strawności (Arseniuk i Oleksiak 2002). W Polsce, w 2018 roku areał uprawy pszenżyta ozimego wynosił około 1,106 $\mathrm{mln}$ ha, a pszenżyta jarego około 0,182 mln ha (Łączyński 2019). W uprawie pszenżyta, podobnie jak dla pozostałych zbóż, dużym zagrożeniem są potencjalnie mykotoksynotwórcze grzyby rodzaju Fusarium występujące na kłosach (FBH) i ziarnie (FDK). Ziarno pszenżyta z uprawy ekologicznej jest komponentem pasz przeznaczonych do ekologicznego chowu zwierząt. Metabolity grzybów zasiedlających ziarno mogą znaleźć się w paszy i kumulować w tkankach zwierząt, a następnie wraz z żywnością zostać spożyte przez ludzi powodując zatrucia. W zależności od rodzaju wytworzonych metabolitów i ich zawartości w żywności lub paszy mogą być silnie toksyczne, zarówno dla ludzi i zwierząt (Wiśniewska i wsp. 2014). Zagrożeniem dla zdrowia ludzi i zwierząt mogą być również licznie występujące na ziarnie zbóż Alternaria alternata i Epicoccum nigrum.

Celem badań była ocena nasilenia fuzariozy kłosów wybranych odmian pszenżyta uprawianego w systemie ekologicznym, oznaczenie grzybów zasiedlających ziarno oraz określenie występowania grzybów potencjalnie mykotoksynotwórczych stanowiących zagrożenie dla zdrowia ludzi i zwierząt.

\section{Materiały i metody / Materials and methods}

Doświadczenia przeprowadzono w latach 2015-2017 na polach z ekologicznym systemem produkcji zlokalizowanych w Grabowie n/Wisłą (51⒉ 'N, 21 $\left.{ }^{\circ} 40^{\prime} \mathrm{E}\right)$ należących do Instytutu Uprawy Nawożenia i Gleboznawstwa - Państwowego Instytutu Badawczego w Puławach oraz w Taraskowie k/Łomży $\left(53^{\circ} 13^{\prime} \mathrm{N}, 2^{\circ} 16^{\prime} \mathrm{E}\right)$ - indywidualnym, ekologicznym gospodarstwie rolnym Kazimierza i Jadwigi Kopacz. W każdym roku obiektem doświadczalnym było 10 odmian pszenżyta ozimego. Obserwacje polowe oceny nasilenia fuzariozy kłosów oraz analizę mykologiczną ziarna wykonano według metod opisanych przez Lenca (2015). Statystyczne opracowanie wyników wykonano:

- analizą frekwencji - testem zgodności chi kwadrat $\left(\chi^{2}\right)$ (dla porównania liczebności ziarna zasiedlonego przez grzyby),

- analizą korelacji (dla określenia zależności pomiędzy najczęściej występującymi gatunkami grzybów zasiedlającymi ziarno).
W latach prowadzenia badań warunki pogodowe (temperatura i opady) odbiegały od wartości średnich wieloletnich. W Taraskowie w 2015 roku już w maju zaobserwowano niedobór opadów, a od czerwca do sierpnia przy wartościach temperatur wyższych niż średnie $\mathrm{z}$ wielolecia $\mathrm{w}$ obu miejscowościach wystąpiła pogłębiająca się susza. Sezon wegetacyjny 2016 był również ciepły i suchy. W Grabowie i Taraskowie temperatury były wyższe od średniej wieloletniej, przy czym w Grabowie susza trwała od maja do końca sezonu wegetacyjnego, a w Taraskowie w lipcu wystąpiły opady przewyższające średnią z wielolecia. Warunki pogodowe panujące w 2016 roku były przyczyną dyskwalifikacji prawy w Taraskowie. W 2017 roku w miesiącach letnich (szczególnie w maju i czerwcu) odnotowano deficyt opadów.

\section{Wyniki i dyskusja / Results and discussion}

Do infekcji i nasilania objawów fuzariozy kłosów potrzebne są odpowiednie warunki pogodowe, a przede wszystkim częste opady występujące w fazie kwitnienia, wysoka wilgotność powietrza oraz wietrzna pogoda ułatwiająca przenoszenie zarodników na inne rośliny. $\mathrm{Na}$ nasilenie choroby znaczny wpływ mają również zabiegi agrotechniczne oraz podatność uprawianych odmian (Bateman i wsp. 2007; Prodi i wsp. 2009; Sadowski i wsp. 2010). W czasie trwania doświadczenia, niewielkie opady w okresie kwitnienia pszenżyta oraz wyższa od przeciętnej temperatura powietrza nie sprzyjały występowaniu fuzariozy kłosów. We wszystkich latach badań objawy chorobowe wystąpiły sporadycznie lub w ogóle ich nie obserwowano, średnio $0,4 \%$ (zakres 0 do 3,0\%).

Nasilenie fuzariozy kłosów nie odzwierciedlało zasiedlenia ziarna przez grzyby rodzaju Fusarium.

Jak podaje Góral (2009) objawy chorobowe na kłosie nie zawsze korelują z zasiedleniem ziarna. Może to występować m.in. przy sprzyjających warunkach pogodowych w okresie kwitnienia i dojrzewania późniejszych odmian lub przy niskiej odporności odmiany na porażenie ziarniaków (typ III) przy jednoczesnej wysokiej odporności (typ II) na porażenia kłosa.

Analiza trzyletnich wyników wykazała istotne różnice w zasiedleniu ziarniaków badanych odmian przez Fusarium spp. W Grabowie porażenie ziarna przez te patogeny wynosiło średnio 4,9\% (1,3-8,6\%). Najniższy procent zasiedlenia stwierdzono na odmianie Subito $(1,3 \%)$, a najwyższy na odmianie Fredro (8,6\%). W Taraskowie (średnio za dwa lata badań) porażenie wynosiło $2,1-13,0 \%$. Najniższy procent zasiedlenia ziarniaków stwierdzono na odmianie Pizarro $(2,1 \%)$, a do grupy odmian o najwyższym porażeniu należały: Twingo (13,0\%), Leontino (12,3\%), Borowik $(11,4 \%)$ i Algoso (10,1\%) (tab. 1).

Duże zróżnicowanie w zasiedleniu ziarna przez Fusarium spp. zaobserwowano również między latami badań, 
np. odmiana Borowik (Grabów) w 2015 roku należała do grupy odmian o najwyższym, a w 2016 roku o najniższym procencie porażonych ziarniaków. Warto jednak zwrócić uwagę, że w Grabowie odmiana Subito we wszystkich latach charakteryzowała się niskim porażeniem ziarna, a odmiana Fredro należała do grupy odmian o najwyższym procencie zasiedlonych ziarniaków (tab. 1).

W badaniach Wiśniewskiej i wsp. (2014) nad odpornością 37 genotypów zbóż na Fusarium culmorum, objawy fuzariozy kłosów występowały w zakresie od 4,8 do 24,7\%, przy czym 31 genotypów wykazywało porażenie do $10 \%$, 4 genotypy od 10 do $20 \%$, a jedynie 2 genotypy powyżej $20 \%$. Wśród nich do silniej porażonych należała odmiana Fredro, która w badaniach własnych wykazywała najwyższy procent zasiedlenia ziarna przez Fusarium spp. O statystycznie istotnym zróżnicowaniu podatności odmian pszenżyta ozimego na F. culmorum donosi Góral (2009). W polowym doświadczeniu infekcyjnym (z inokulacją) średnie nasilenie fuzariozy kłosów w latach 2002-2004 dla 28 odmian wyniosło $23,3 \%$, a zakres reakcji odmian wynosił 14,1-39,9\%. Zasiedlenie ziarniaków przez grzyby wyniosło średnio $42,0 \%$, a zróżnicowanie między odmianami zawierało się w zakresie 21,6-77,0\%.

Nasilenie występowania Fusarium spp. zależy również od lokalizacji uprawy. Analizując porażenie ziarna poszczególnych odmian w 2015 roku można zauważyć, że niektóre z nich podobnie, a inne różnie reagowały w zależności od miejscowości, w której były uprawiane. Ziarno odmian Pizarro i Subito pochodzące zarówno z Grabowa, jak i Taraskowa należało do grupy o najniższym stopniu zasiedlenia przez Fusarium spp., natomiast ziarno odmiany Borowik z Grabowa należało do odmian o najwyższym procencie porażenia, a z ziarna pochodzącego z Taraskowa nie izolowano tych patogenów (tab. 1).

Zasiedlenie ziarna przez poszczególne gatunki Fusarium spp. było zróżnicowane w zależności od roku badań i lokalizacji (tab. 2, 3). Z ziarna pochodzącego z obu miejscowości izolowano głównie $F$. poae i $F$. avenaceum. W Grabowie stanowiły one odpowiednio około 54\% i 24\%, a w Taraskowie 33\% i 35\% ogólnej liczby wyizolowanych Fusarium spp. Uwage zwraca zasiedlenie ziarna przez F. equseti w Taraskowie w 2017 roku. Ponadto, w niewielkich ilościach lub sporadycznie izolowano $F$. graminearum, F. langsethiae, F. sporotrichioides i F. tricinctum (tab. 2, 3). Występowanie gatunków potencjalnie toksynotwórczych może powodować zanieczyszczenia trującymi metabolitami. Ziarno może być zanieczyszczone mykotoksynami nawet jeśli nie występuje zmniejszenie jego plonu (Wiśniewska i wsp. 2014). Jak podają Parry i Nicholson (1996), F. poae uważany za słabego patogena, w niniejszych badaniach najliczniej zasiedlający ziarno pszenżyta, jest również gatunkiem mykotoksynotwórczym.

Miedaner i wsp. (2001) stwierdzili, że pszenżyto było bardziej odporne na FBH aniżeli pszenica, ale mniej odporne od żyta, jęczmienia i owsa. W ostatnich latach pojawiają się doniesienia o nasilającym się zagrożeniu pszenżyta grzybami rodzaju Fusarium i toksynami fuzaryjnymi. Toksyny te mogą być kumulowane w ziarnie pszenżyta na poziomie zanieczyszczenia ziarna pszenicy lub wyższym, nawet przy niższym nasileniu objawów fuzariozy na kłosach

Tabela 1. Zasiedlenie przez Fusarium spp. ziarna pszenżyta ozimego uprawianego w systemie ekologicznym w Grabowie i Taraskowie w latach 2015-2017

Table 1. Fungi of genera Fusarium isolated from the grain of winter triticale cultivated in the ecological system in Grabów and Taraskowo, 2015-2017

\begin{tabular}{|c|c|c|c|c|c|c|c|}
\hline \multirow{3}{*}{$\begin{array}{l}\text { Odmiana } \\
\text { Cultivar }\end{array}$} & \multicolumn{7}{|c|}{ \% zasiedlonych ziarniaków przez Fusarium spp. - \% of grains colonized by Fusarium spp. } \\
\hline & \multicolumn{4}{|c|}{ Grabów } & \multicolumn{3}{|c|}{ Taraskowo } \\
\hline & 2015 & 2016 & 2017 & $2015-2017$ & 2015 & 2017 & $2015-2017$ \\
\hline Algoso & $8,5 \mathrm{abc}$ & $6,0 \mathrm{abc}$ & $0,0 \mathrm{c}$ & 4,8 bcd & $5,1 \mathrm{~b}$ & $15,0 \mathrm{~b}$ & $10,1 \mathrm{ab}$ \\
\hline Borowik & $10,3 \mathrm{ab}$ & $3,2 \mathrm{~cd}$ & $3,5 \mathrm{a}$ & $5,7 \mathrm{bc}$ & $0,0 \mathrm{c}$ & $22,8 \mathrm{a}$ & $11,4 \mathrm{a}$ \\
\hline Fredro & $11,5 \mathrm{a}$ & $9,2 \mathrm{a}$ & $5,0 \mathrm{a}$ & $8,6 \mathrm{a}$ & $4,8 \mathrm{~b}$ & $11,8 \mathrm{bcd}$ & $8,3 \mathrm{bc}$ \\
\hline Grenado & $6,8 \mathrm{bc}$ & $5,0 \mathrm{bc}$ & $0,0 \mathrm{c}$ & $3,9 \mathrm{de}$ & $0,0 \mathrm{c}$ & 9,3 cde & $4,7 \mathrm{~d}$ \\
\hline Leontino & $13,0 \mathrm{a}$ & $5,3 \mathrm{bc}$ & $0,0 \mathrm{c}$ & $6,1 \mathrm{~b}$ & $11,0 \mathrm{a}$ & $13,5 \mathrm{bc}$ & $12,3 \mathrm{a}$ \\
\hline Pizarro & $3,3 \mathrm{de}$ & $5,3 \mathrm{bc}$ & $0,0 \mathrm{c}$ & $2,9 \mathrm{e}$ & $0,0 \mathrm{c}$ & $4,2 \mathrm{f}$ & $2,1 \mathrm{e}$ \\
\hline Subito & $1,8 \mathrm{e}$ & $1,2 \mathrm{~d}$ & $1,0 \mathrm{~b}$ & $1,3 \mathrm{f}$ & $0,0 \mathrm{c}$ & 10,0 cde & $5,0 \mathrm{~d}$ \\
\hline Tomko & $8,8 \mathrm{ab}$ & $5,8 \mathrm{abc}$ & $2,5 a b$ & $5,7 \mathrm{bc}$ & $4,5 \mathrm{~b}$ & $8,2 \mathrm{de}$ & $6,4 \mathrm{~cd}$ \\
\hline Tulus & $5,0 \mathrm{~cd}$ & $6,5 \mathrm{ab}$ & $1,0 \mathrm{~b}$ & 4,2 cde & $2,5 \mathrm{~b}$ & $6,2 \mathrm{ef}$ & $4,4 \mathrm{~d}$ \\
\hline Twingo & $10,3 \mathrm{ab}$ & $5,0 \mathrm{bc}$ & $2,5 \mathrm{ab}$ & $5,9 \mathrm{bc}$ & $5,0 \mathrm{~b}$ & $21,0 \mathrm{a}$ & $13,0 \mathrm{a}$ \\
\hline Średnio - Mean & 7,9 A & 5,3 & $1,6 \mathrm{~B}$ & 4,9 & $3,3 \mathrm{~B}$ & $12,2 \mathrm{~A}$ & 7,8 \\
\hline
\end{tabular}

Wartości w kolumnach oznaczone różnymi małymi literami wskazują istotną różnicę między odmianami

Values in columns marked with different lowercase letters indicate a significant difference between variations

Wartości w wierszach oznaczone różnymi wielkimi literami wskazują istotną różnicę między latami badań

The values in the lines marked with different capital letters indicate a significant difference between the years of research 
Tabela 2. Gatunki Fusarium spp. wyizolowane z ziarniaków pszenżyta ozimego uprawianego w Grabowie w systemie ekologicznym, 2015-2017 (\% zasiedlonych ziarniaków)

Table 2. Fusarium species isolated from winter triticale kernels grown in Grabów in the ecological system, $2015-2017$ (\% of colonized kernels)

\begin{tabular}{|c|c|c|c|c|c|c|c|c|c|c|c|}
\hline \multirow[t]{2}{*}{$\begin{array}{l}\text { Odmiana } \\
\text { Cultivar }\end{array}$} & 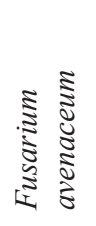 & 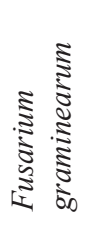 & 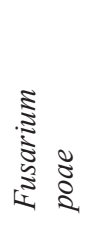 & 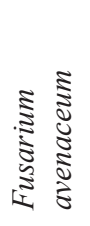 & 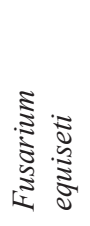 & 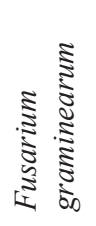 & 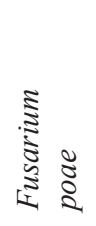 & 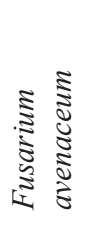 & 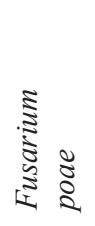 & 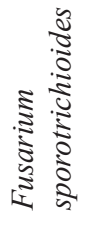 & 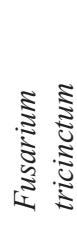 \\
\hline & \multicolumn{3}{|c|}{2015} & \multicolumn{4}{|c|}{2016} & \multicolumn{4}{|c|}{2017} \\
\hline Algoso & - & 5,0 & 3,5 & 3,2 & - & 1,0 & 1,8 & - & - & - & - \\
\hline Borowik & 3,5 & 1,8 & 5,0 & - & - & 3,2 & - & - & 3,5 & - & - \\
\hline Fredro & 5,0 & 1,5 & 5,0 & 3,2 & - & 1,0 & 5,0 & 3,5 & 1,5 & - & - \\
\hline Grenado & - & - & 6,8 & - & - & - & 5,0 & - & - & - & - \\
\hline Leontino & - & 5,0 & 8,0 & 1,8 & - & - & 3,5 & - & - & - & - \\
\hline Pizarro & - & 3,3 & - & 1,8 & - & - & 3,5 & - & - & - & - \\
\hline Subito & - & - & 1,8 & - & - & 1,2 & - & - & - & 1,0 & - \\
\hline Tomko & - & 1,8 & 7,0 & - & 0,8 & - & 5,0 & 1,0 & 1,5 & - & - \\
\hline Tulus & - & - & 5,0 & 5,0 & - & - & 1,5 & - & 1,0 & - & - \\
\hline Twingo & 3,3 & 3,5 & 3,5 & 3,2 & - & - & 1,8 & 1,0 & - & - & 1,5 \\
\hline Średnio - Mean & 1,2 & 2,2 & 4,6 & 1,8 & 0,1 & 0,6 & 2,7 & 0,6 & 0,8 & 0,1 & 0,2 \\
\hline
\end{tabular}

Tabela 3. Gatunki Fusarium spp. wyizolowane z ziarniaków pszenżyta ozimego uprawianego w Taraskowie w systemie ekologicznym, 2015 i 2017 (\% zasiedlonych ziarniaków)

Table 3. Fusarium species isolated from winter triticale kernels grown in Taraskowo in the ecological system, 2015 and 2017 (\% of colonized kernels)

\begin{tabular}{|c|c|c|c|c|c|c|c|c|c|c|}
\hline \multirow[t]{2}{*}{$\begin{array}{l}\text { Odmiana } \\
\text { Cultivar }\end{array}$} & 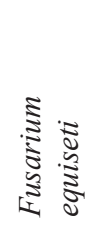 & 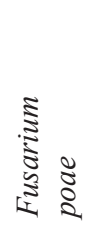 & 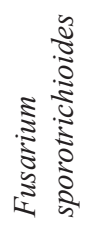 & 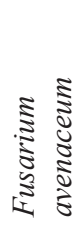 & 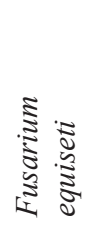 & 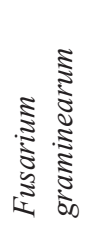 & 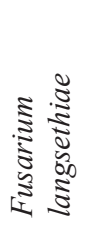 & 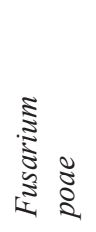 & 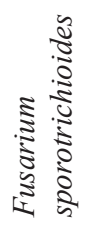 & 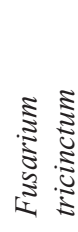 \\
\hline & \multicolumn{3}{|c|}{2015} & \multicolumn{7}{|c|}{2017} \\
\hline Algoso & 3,3 & 1,8 & - & 10,0 & - & 5,0 & - & - & - & - \\
\hline Borowik & - & - & - & 6,8 & - & - & 3,0 & 5,0 & 3,5 & 4,5 \\
\hline Fredro & 1,5 & 3,3 & - & 6,8 & - & - & - & 5,0 & - & - \\
\hline Grenado & - & - & - & 6,8 & 1,5 & 1,0 & - & - & - & - \\
\hline Leontino & - & 11,0 & - & 8,2 & - & - & - & 3,5 & 1,8 & - \\
\hline Pizarro & - & - & - & 1,5 & - & 1,2 & - & 1,5 & - & - \\
\hline Subito & - & - & - & 1,5 & - & - & - & 8,5 & - & - \\
\hline Tomko & - & 3,5 & 1,0 & 3,2 & - & - & - & 5,0 & - & - \\
\hline Tulus & 1,0 & 1,5 & - & 5,0 & - & - & - & - & - & 1,2 \\
\hline Twingo & - & 5,0 & - & 1,5 & 18,0 & - & - & - & - & 1,5 \\
\hline Średnio - Mean & 0,6 & 2,6 & 0,1 & 5,1 & 2,0 & 0,7 & 0,3 & 2,9 & 0,5 & 0,7 \\
\hline
\end{tabular}

i ziarniakach (Wiśniewska i wsp. 2014). W badaniach Górala i wsp. (2016) pszenżyto ozime wykazywało niższe objawy fuzariozy kłosów i uszkodzenia ziarniaków aniżeli pszenica ozima, jednak zawartość trichotecenów typu B w ziarniakach pszenżyta była wyższa, a zearalenonu na tym samym poziomie, jak w ziarnie pszenicy. Veitch i wsp. 
(2008) w trzyletnich doświadczeniach badali odporność na fuzariozę kłosów kanadyjskich odmian pszenżyta ozimego i jarego. Autorzy porównywali procent zasiedlenia ziarniaków oraz zawartość DON w ziarnie pszenżyta i pszenicy. Zarówno odmiany pszenżyta ozimego, jak i jarego okazały się bardziej podatne na fuzariozę kłosów niż odmiany pszenicy. Wysoką podatność kanadyjskich odmian pszenżyta wykazali również Comeau i wsp. (2008). Według Górala i Ochodzkiego (2006) duże zróżnicowanie odporności polskich i kanadyjskich odmian pszenżyta wynika z całkowicie różnego rodowodu obu grup odmian.

W badaniach własnych dominującym grzybem zasiedlającym ziarno pszenżyta ozimego pochodzącego z obu miejscowości był A. alternata. Procent zasiedlonych ziarniaków był zróżnicowany w zależności od roku badań (np. średnio w 2015 i 2017 roku w Grabowie; 49,7\% i 91,7\%), odmiany (np. w 2015 roku w Grabowie, Grenado i Algoso; 40,0\% i 61,8\%) i lokalizacji uprawy zboża

Tabela 4. Alternaria alternata wyizolowany z ziarniaków pszenżyta ozimego uprawianego w dwóch miejscowościach w systemie ekologicznym, 2015-2017 (\% zasiedlonych ziarniaków)

Table 4. Alternaria alternata isolated from winter triticale kernels grown in two locations in the ecological system, $2015-2017$ (\% of colonized kernels)

\begin{tabular}{l|c|c|c|c|c|c|c}
\hline \multirow{2}{*}{$\begin{array}{c}\text { Odmiana } \\
\text { Cultivar }\end{array}$} & \multicolumn{4}{|c|}{ Grabów } & \multicolumn{3}{c}{ Taraskowo } \\
\cline { 2 - 8 } & 2015 & 2016 & 2017 & $2015-2017$ & 2015 & 2017 & $2015 \mathrm{i} 2017$ \\
\hline Algoso & $61,8 \mathrm{a}$ & $88,2 \mathrm{ab}$ & $86,8 \mathrm{bc}$ & $78,9 \mathrm{a}$ & $82,0 \mathrm{ab}$ & $76,5 \mathrm{~cd}$ & $79,3 \mathrm{abc}$ \\
\hline Borowik & $50,0 \mathrm{~cd}$ & $91,5 \mathrm{a}$ & $91,8 \mathrm{ab}$ & $77,8 \mathrm{ab}$ & $83,3 \mathrm{a}$ & $68,2 \mathrm{e}$ & $75,8 \mathrm{bc}$ \\
\hline Fredro & $50,0 \mathrm{~cd}$ & $88,0 \mathrm{ab}$ & $95,0 \mathrm{a}$ & $77,7 \mathrm{ab}$ & $78,5 \mathrm{abc}$ & $71,5 \mathrm{de}$ & $75,0 \mathrm{~cd}$ \\
\hline Grenado & $40,0 \mathrm{f}$ & $83,2 \mathrm{bc}$ & $95,0 \mathrm{a}$ & $72,7 \mathrm{c}$ & $81,8 \mathrm{ab}$ & $80,0 \mathrm{bc}$ & $80,9 \mathrm{a}$ \\
\hline Leontino & $43,3 \mathrm{ef}$ & $91,5 \mathrm{a}$ & $96,5 \mathrm{a}$ & $77,1 \mathrm{ab}$ & $74,0 \mathrm{~cd}$ & $85,0 \mathrm{ab}$ & $79,5 \mathrm{abc}$ \\
\hline Pizarro & $58,3 \mathrm{ab}$ & $78,2 \mathrm{~cd}$ & $95,0 \mathrm{a}$ & $77,2 \mathrm{ab}$ & $71,8 \mathrm{~cd}$ & $88,2 \mathrm{a}$ & $80,0 \mathrm{ab}$ \\
\hline Subito & $47,0 \mathrm{de}$ & $93,0 \mathrm{a}$ & $91,5 \mathrm{ab}$ & $77,2 \mathrm{ab}$ & $75,0 \mathrm{bcd}$ & $86,8 \mathrm{ab}$ & $80,9 \mathrm{a}$ \\
\hline Tomko & $45,0 \mathrm{def}$ & $90,0 \mathrm{ab}$ & $86,8 \mathrm{bc}$ & $73,9 \mathrm{bc}$ & $78,3 \mathrm{abc}$ & $85,0 \mathrm{ab}$ & $81,7 \mathrm{a}$ \\
\hline Tulus & $55,0 \mathrm{bc}$ & $86,5 \mathrm{ab}$ & $96,8 \mathrm{a}$ & $79,4 \mathrm{a}$ & $75,0 \mathrm{bcd}$ & $85,0 \mathrm{ab}$ & $80,0 \mathrm{ab}$ \\
\hline Twingo & $46,8 \mathrm{de}$ & $73,2 \mathrm{~d}$ & $81,5 \mathrm{c}$ & $67,2 \mathrm{~d}$ & $68,3 \mathrm{~d}$ & $73,2 \mathrm{cde}$ & $70,8 \mathrm{~d}$ \\
\hline Średnio - Mean & 49,7 & 86,3 & 91,7 & 75,9 & 76,8 & 79,9 & 78,4 \\
\hline
\end{tabular}

Wartości oznaczone różnymi małymi literami wskazują istotną różnicę między odmianami

Values marked with different lowercase letters indicate a significant difference between variations

Tabela 5. Epicoccum nigrum wyizolowany z ziarniaków pszenżyta ozimego uprawianego w dwóch miejscowościach w systemie ekologicznym, 2015-2017 (\% zasiedlonych ziarniaków)

Tabela 5. Epicoccum nigrum isolated from winter triticale kernels grown in two locations in the ecological system, 2015-2017 (\% of colonized kernels)

\begin{tabular}{|c|c|c|c|c|c|c|c|}
\hline \multirow{2}{*}{$\begin{array}{l}\text { Odmiana } \\
\text { Cultivar }\end{array}$} & \multicolumn{4}{|c|}{ Grabów } & \multicolumn{3}{|c|}{ Taraskowo } \\
\hline & 2015 & 2016 & 2017 & 2015-2017 & 2015 & 2017 & 2015 i 2017 \\
\hline Algoso & $35,0 \mathrm{c}^{1}$ & $13,5 \mathrm{~b}$ & $16,8 \mathrm{a}$ & $21,8 \mathrm{~b}$ & $10,0 \mathrm{bc}$ & $11,5 \mathrm{c}$ & $10,8 \mathrm{~cd}$ \\
\hline Borowik & 26,8 ef & 8,2 de & $8,2 \mathrm{~d}$ & $14,4 \mathrm{~d}$ & $8,3 \mathrm{c}$ & $6,8 \mathrm{~d}$ & $7,6 \mathrm{e}$ \\
\hline Fredro & $25,0 \mathrm{f}$ & $10,0 \mathrm{~cd}$ & $11,5 \mathrm{c}$ & $15,5 \mathrm{~d}$ & $3,5 \mathrm{~d}$ & $11,8 \mathrm{c}$ & $7,7 \mathrm{e}$ \\
\hline Grenado & $43,3 \mathrm{a}$ & $11,8 \mathrm{bc}$ & $20,0 \mathrm{a}$ & $25,0 \mathrm{a}$ & $15,0 \mathrm{a}$ & $13,2 \mathrm{bc}$ & $14,1 \mathrm{ab}$ \\
\hline Leontino & $36,8 \mathrm{bc}$ & $6,8 \mathrm{e}$ & $11,5 \mathrm{c}$ & $18,4 \mathrm{c}$ & $11,5 \mathrm{~b}$ & $5,0 \mathrm{~d}$ & $8,3 \mathrm{e}$ \\
\hline Pizarro & $33,0 \mathrm{~cd}$ & $21,8 \mathrm{a}$ & $15,0 \mathrm{~b}$ & $23,3 \mathrm{ab}$ & $5,0 \mathrm{~d}$ & $3,0 \mathrm{e}$ & $4,0 \mathrm{~g}$ \\
\hline Subito & $41,8 \mathrm{ab}$ & $11,8 \mathrm{bc}$ & $16,5 \mathrm{~b}$ & $23,4 \mathrm{ab}$ & $5,0 \mathrm{~d}$ & $13,2 \mathrm{bc}$ & $9,1 \mathrm{de}$ \\
\hline Tomko & 30,0 de & $10,0 \mathrm{~cd}$ & $16,8 \mathrm{ab}$ & $18,9 \mathrm{c}$ & $5,0 \mathrm{~d}$ & $6,8 \mathrm{~d}$ & $5,9 \mathrm{f}$ \\
\hline Tulus & $25,0 \mathrm{f}$ & $13,2 \mathrm{~b}$ & $15,0 \mathrm{~b}$ & $17,7 \mathrm{c}$ & $10,0 \mathrm{bc}$ & $15,0 \mathrm{~b}$ & $12,5 \mathrm{bc}$ \\
\hline Twingo & $33,3 \mathrm{~cd}$ & $20,0 \mathrm{a}$ & $11,8 \mathrm{c}$ & $21,7 \mathrm{~b}$ & $8,3 \mathrm{c}$ & $21,8 \mathrm{a}$ & $15,1 \mathrm{a}$ \\
\hline Średnio - Mean & 33,0 & 12,7 & 14,3 & 20,0 & 8,2 & 10,8 & 9,5 \\
\hline
\end{tabular}

Wartości oznaczone różnymi małymi literami wskazują istotną różnicę między odmianami

Values marked with different lowercase letters indicate a significant difference between variations 
(np. 2015 rok średnio w Grabowie i Taraskowie; 49,7\% i 76,8\%) (tab. 4).

Z ziarna pszenżyta ozimego licznie izolowano również E. nigrum. Podobnie, jak przy A. alternata procent zasiedlenia ziarniaków był zróżnicowany i zależał od roku badań (np. średnio w 2015 i 2016 roku w Grabowie; 33,0\% i 12,7\%), odmiany (np. 2017 rok w Taraskowie, Pizarro i Twingo; 3,0\% i 21,8\%) i lokalizacji uprawy zboża (np. 2015 rok średnio w Grabowie i Taraskowie; 33,0\% i 8,2\%) (tab. 5).

Te licznie zasiedlające ziarno pszenżyta dwa gatunki grzybów niekorzystnie wpływają na jakość paszy. Alternaria spp. mogą produkować metabolity wtórne, takie jak kwas tenuazonowy (TA), alternariol $(\mathrm{AOH})$, alternatorol- eter monometylowy (AME) i altenuen (ALT), które są toksyczne, genotoksyczne i mutagenne. Z kolei E. nigrum produkuje alergen glikoproteiny Epi p 1, który wiąże się z immunoglobulinami E (IgE), a reagując krzyżowo z innymi grzybami np. A. alternata, Curvularia lunata, Cladosporium herbarum i Penicillium citrinum może powodować choroby układu oddechowego, w tym alergiczną astmę, nieżyt nosa, zapalenie płuc o podwyższonej wrażliwości oraz alergiczne grzybicze zapalenie zatok (Bisht i wsp. 2002; Flannigan i wsp. 2011; Ramires i wsp. 2018).

Wśród innych rodzajów (gatunków) grzybów zasiedlających ziarno pszenżyta ozimego izolowano: Acremoniella fusca, Arthrinium phaeospermum, Aureobasidium boleyi,

Tabela 6. Korelacja między Alternaria alternata - Fusarium spp.

Table 6. Correlation between Alternaria alternata - Fusarium spp.

\begin{tabular}{|c|c|c|c|c|c|c|}
\hline $\begin{array}{l}\text { Lata } \\
\text { Years }\end{array}$ & $\begin{array}{c}\text { Współczynnik regresji } \\
\text { liniowej „,b” } \\
\text { Linear regression } \\
\text { coefficient „,b” }\end{array}$ & $\begin{array}{c}\text { Współczynnik ,a” } \\
\text { Coefficient „a” }\end{array}$ & $\begin{array}{l}\text { Współczynnik } \\
\text { korelacji „r” } \\
\text { Correlation } \\
\text { coefficient „," }\end{array}$ & $\begin{array}{l}\mathrm{F}_{\mathrm{obl}} / \mathrm{F}_{\mathrm{tab}} \\
\mathrm{F}_{\mathrm{cal}} / \mathrm{F}_{\mathrm{tab}}\end{array}$ & $\begin{array}{c}\text { Równanie regresji Yp } \\
\text { Linear regression } \\
\text { equation Yp }\end{array}$ & $\begin{array}{l}\text { Korelacja } \\
\text { Correlation }\end{array}$ \\
\hline \multicolumn{7}{|c|}{ Grabów n/Wisłą } \\
\hline 2015 & $-0,148$ & 15,311 & $-0,279$ & $\mathrm{~F}_{\mathrm{obl}}<\mathrm{F}_{\mathrm{tab}}$ & $y=-0,148 x+15,311$ & nie - no \\
\hline 2016 & $-0,064$ & 10,784 & $-0,197$ & $\mathrm{~F}_{\mathrm{obl}}<\mathrm{F}_{\mathrm{tab}}$ & $y=-0,064 x+10,784$ & nie - no \\
\hline 2017 & $-0,066$ & 7,641 & $-0,193$ & $\mathrm{~F}_{\mathrm{obl}}<\mathrm{F}_{\mathrm{tab}}$ & $y=-0,066 x+7,641$ & nie - no \\
\hline 2015-2017 & $-0,121$ & 14,102 & $-0,655$ & $\mathrm{~F}_{\mathrm{obl}}>\mathrm{F}_{\mathrm{tab}}$ & $\mathrm{y}=-0,121 \mathrm{x}+14,102$ & tak - yes \\
\hline \multicolumn{7}{|c|}{ Taraskowo } \\
\hline 2015 & $-0,172$ & 16,528 & $-0,235$ & $\mathrm{~F}_{\mathrm{obl}}<\mathrm{F}_{\mathrm{tab}}$ & $y=-0,172 x+16,528$ & nie - no \\
\hline 2017 & $-0,688$ & 67,196 & $-0,812$ & $\mathrm{~F}_{\mathrm{obl}}>\mathrm{F}_{\mathrm{tab}}$ & $y=-0,688 x+67,196$ & tak - yes \\
\hline 2015-2017 & $-0,295$ & 30,845 & $-0,273$ & $\mathrm{~F}_{\mathrm{obl}}<\mathrm{F}_{\mathrm{tab}}$ & $y=-0,295 x+30,745$ & nie - no \\
\hline \multicolumn{7}{|c|}{ Grabów n/Wisłą + Taraskowo } \\
\hline 2015-2017 & $-0,124$ & 15,558 & $-0,376$ & $\mathrm{~F}_{\mathrm{obl}}>\mathrm{F}_{\mathrm{tab}}$ & $\mathrm{y}=-0,124 \mathrm{x}+15,558$ & tak - yes \\
\hline
\end{tabular}

Tabela 7. Korelacja między Epicoccum nigrum - Fusarium spp.

Table 7. Correlation between Epicoccum nigrum - Fusarium spp.

\begin{tabular}{|c|c|c|c|c|c|c|}
\hline $\begin{array}{l}\text { Lata } \\
\text { Years }\end{array}$ & $\begin{array}{c}\text { Współczynnik regresji } \\
\text { liniowej „,b” } \\
\text { Linear regression } \\
\text { coefficient „,b” }\end{array}$ & $\begin{array}{c}\text { Współczynnik ,a” } \\
\text { Coefficient „,a” }\end{array}$ & $\begin{array}{l}\text { Współczynnik } \\
\text { korelacji „r” } \\
\text { Correlation } \\
\text { coefficient „,r" }\end{array}$ & $\begin{array}{l}\mathrm{F}_{\text {obl }} / \mathrm{F}_{\text {tab }} \\
\mathrm{F}_{\text {cal }} / \mathrm{F}_{\text {tab }}\end{array}$ & $\begin{array}{c}\text { Równanie regresji Yp } \\
\text { Linear regression } \\
\text { equation } \mathrm{Yp}\end{array}$ & $\begin{array}{l}\text { Korelacja } \\
\text { Correlation }\end{array}$ \\
\hline \multicolumn{7}{|c|}{ Grabów n/Wisłą } \\
\hline 2015 & $-0,177$ & 13,777 & $-0,315$ & $\mathrm{~F}_{\mathrm{obl}}<\mathrm{F}_{\mathrm{tab}}$ & $\mathrm{y}=-0,177 \mathrm{x}+13,777$ & nie - no \\
\hline 2016 & 0,002 & 5,219 & 0,006 & $\mathrm{~F}_{\mathrm{obl}}<\mathrm{F}_{\mathrm{tab}}$ & $y=0,002 x+5,219$ & nie - no \\
\hline 2017 & $-0,296$ & 5,794 & $-0,590$ & $\mathrm{~F}_{\mathrm{obl}}>\mathrm{F}_{\mathrm{tab}}$ & $y=-0,296 x+5,794$ & tak - yes \\
\hline 2015-2017 & 0,142 & 2,070 & 0,408 & $\mathrm{~F}_{\mathrm{obl}}>\mathrm{F}_{\mathrm{tab}}$ & $y=0,142 x+2,070$ & tak - yes \\
\hline \multicolumn{7}{|c|}{ Taraskowo } \\
\hline 2015 & 0,127 & 2,250 & 0,129 & $\mathrm{~F}_{\mathrm{obl}}<\mathrm{F}_{\mathrm{tab}}$ & $y=0,127 x+2,250$ & nie - no \\
\hline 2017 & 0,321 & 8,726 & 0,298 & $\mathrm{~F}_{\mathrm{obl}}<\mathrm{F}_{\mathrm{tab}}$ & $\mathrm{y}=0,321 \mathrm{x}+8,726$ & nie - no \\
\hline 2015-2017 & 0,517 & 2,838 & 0,370 & $\mathrm{~F}_{\mathrm{obl}}<\mathrm{F}_{\mathrm{tab}}$ & $\mathrm{y}=0,517 \mathrm{x}+2,838$ & nie - no \\
\hline \multicolumn{7}{|c|}{ Grabów n/Wisłą + Taraskowo } \\
\hline 2015-2017 & 0,065 & 5,019 & 0,126 & $\mathrm{~F}_{\mathrm{obl}}<\mathrm{F}_{\mathrm{tab}}$ & $y=0,065 x+5,019$ & nie - no \\
\hline
\end{tabular}


Tabela 8. Korelacja między Alternaria alternata - Epicoccum nigrum Table 8. Correlation between Alternaria alternata-Epicoccum nigrum

\begin{tabular}{|c|c|c|c|c|c|c|}
\hline $\begin{array}{l}\text { Lata } \\
\text { Years }\end{array}$ & $\begin{array}{c}\text { Współczynnik regresji } \\
\text { liniowej „b” } \\
\text { Linear regression } \\
\text { coefficient „,b” }\end{array}$ & $\begin{array}{c}\text { Współczynnik ,a” } \\
\text { Coefficient „a" }\end{array}$ & $\begin{array}{l}\text { Współczynnik } \\
\text { korelacji „,r” } \\
\text { Correlation } \\
\text { coefficient „r" }\end{array}$ & $\begin{array}{l}\mathrm{F}_{\text {obl }} / \mathrm{F}_{\text {tab }} \\
\mathrm{F}_{\text {cal }} / \mathrm{F}_{\text {tab }}\end{array}$ & $\begin{array}{c}\text { Równanie regresji } \\
\text { Yp Linear regression } \\
\text { equation Yp }\end{array}$ & $\begin{array}{c}\text { Korelacja } \\
\text { Correlation }\end{array}$ \\
\hline \multicolumn{7}{|c|}{ Grabów n/Wisłą } \\
\hline 2015 & $-0,373$ & 51,547 & $-0,394$ & $\mathrm{~F}_{\mathrm{obl}}<\mathrm{F}_{\mathrm{tab}}$ & $Y=-0,373 x+51,547$ & nie - no \\
\hline 2016 & $-0,655$ & 69,228 & $-0,868$ & $\mathrm{~F}_{\mathrm{obl}}>\mathrm{F}_{\mathrm{tab}}$ & $Y=-0,655 x+69,228$ & tak-yes \\
\hline 2017 & 0,008 & 13,540 & 0,012 & $\mathrm{~F}_{\mathrm{obl}}<\mathrm{F}_{\mathrm{tab}}$ & $Y=0,008 x+13,540$ & nie - no \\
\hline 2015-2017 & $-0,476$ & 56,176 & $-0,896$ & $\mathrm{~F}_{\mathrm{obl}}>\mathrm{F}_{\mathrm{tab}}$ & $Y=-0,476 x+56,176$ & tak-yes \\
\hline \multicolumn{7}{|c|}{ Taraskowo } \\
\hline 2015 & 0,188 & $-6,272$ & 0,253 & $\mathrm{~F}_{\mathrm{obl}}<\mathrm{F}_{\mathrm{tab}}$ & $Y=0,188 x-6,272$ & nie - no \\
\hline 2017 & $-0,249$ & 30,721 & $-0,320$ & $\mathrm{~F}_{\mathrm{obl}}<\mathrm{F}_{\mathrm{tab}}$ & $Y=-0,249 x+30,721$ & nie - no \\
\hline 2015-2017 & $-0,046$ & 13,076 & $-0,059$ & $\mathrm{~F}_{\mathrm{obl}}<\mathrm{F}_{\mathrm{tab}}$ & $Y=-0,046 x+13076$ & nie - no \\
\hline \multicolumn{7}{|c|}{ Grabów n/Wisłą + Taraskowo } \\
\hline 2015-2017 & $-0,474$ & 52,228 & $-0,741$ & $\mathrm{~F}_{\mathrm{obl}}>\mathrm{F}_{\mathrm{tab}}$ & $\mathrm{Y}=-0,474 \mathrm{x}+52,228$ & tak - yes \\
\hline
\end{tabular}

Aureobasidium pullulans, Bipolaris sorokiniana, Botrytis cinerea, Chaetomium spp., Cladosporium herbarum, Gelasinospora cerealis, Gonatobotrys simplex, Khuskia oryzae, Mucor spp., Penicillium spp. i Trichoderma viride. Niektóre z nich w poszczególnych latach lub lokalizacjach wystąpiły liczniej aniżeli pozostałe. Ziarno pochodzące $z$ uprawy w Taraskowie w 2015 roku w dość dużym procencie zasiedlone było przez $A$. boleyi (średnio 11,5\%; od 1,8\% na odmianie Leontinio do $23,5 \%$ na odmianie Borowik). W ziarnie pochodzącym z uprawy w Grabowie w 2017 roku liczniej wystąpiły: Khuskia oryzae (średnio 4,6\%; od 1,0\% na odmianie Tomko do $11,5 \%$ na odmianie Algoso) oraz G. simplex (średnio 4,6\%; od $0,0 \%$ na odmianach: Borowik, Tomko i Twingo do 20,0\% na odmianie Tulus).

Stwierdzono występowanie zależności pomiędzy zasiedleniem ziarna przez A. alternata a Fusarium spp., E. nigrum a Fusarium spp. oraz między $A$. alternata a E. nigrum. Nie wystąpiły one jednak w każdym roku badań.

Analiza korelacji przeprowadzona na wszystkich wynikach badań uzyskanych w latach 2015-2017 zarówno w Grabowie, jak i Taraskowie wykazała słabą ujemną korelację w zasiedleniu ziarna przez A. alternata i Fusarium $\mathrm{spp}$. $\left(\mathrm{r}=-0,376 ; \mathrm{F}_{\mathrm{obl}}>\mathrm{F}_{\mathrm{tab}}\right)$. Na ziarnie pochodzącym $\mathrm{z}$ uprawy w Grabowie ujemną korelację stwierdzono podczas analizy wyników $\mathrm{z}$ trzech lat badań $(\mathrm{r}=-0,655$; $\mathrm{F}_{\mathrm{obl}}>\mathrm{F}_{\mathrm{tab}}$ ), a na ziarnie pochodzącym $\mathrm{z}$ uprawy $\mathrm{w}$ Taraskowie w analizie wyników z 2017 roku $\left(\mathrm{r}=-0,812 ; \mathrm{F}_{\mathrm{obl}}>\mathrm{F}_{\mathrm{tab}}\right)$ (tab. 6).

Ujemną korelację w zasiedleniu przez E. nigrum i $F u$ sarium spp. ziarna pochodzącego z uprawy w Grabowie wykazano w 2017 roku $\left(\mathrm{r}=-0,590 ; \mathrm{F}_{\mathrm{obl}}>\mathrm{F}_{\mathrm{tab}}\right)$ oraz dodatnią podczas analizy wyników $\mathrm{z}$ trzech lat badan $(\mathrm{r}=0,408$; $\mathrm{F}_{\mathrm{obl}}>\mathrm{F}_{\mathrm{tab}}$ ) (tab. 7).

Na podstawie wszystkich wyników badań uzyskanych w latach 2015-2017 stwierdzono ujemną korelację w zasiedleniu ziarna przez A. alternata i E. nigrum ( $\mathrm{r}=-0,741$; $\mathrm{F}_{\text {obl }}>\mathrm{F}_{\text {tab }}$ ). Na ziarnie pochodzącym $\mathrm{z}$ uprawy w Grabowie ujemną korelację stwierdzono analizując wyniki z trzech lat badań $\left(\mathrm{r}=-0,896 ; \mathrm{F}_{\mathrm{obl}}>\mathrm{F}_{\mathrm{tab}}\right)$ oraz w 2016 roku $(\mathrm{r}=-0,868$; $\left.\mathrm{F}_{\text {obl }}>\mathrm{F}_{\mathrm{tab}}\right)($ tab. 8).

\section{Wnioski / Conclusions}

1. Brak objawów fuzariozy kłosów nie świadczy o braku porażenia ziarna przez Fusarium spp.

2. Do uprawy ekologicznej najbardziej przydatnymi z badanych odmian pszenżyta ozimego pod kątem zmniejszenia zagrożenia infekcją przez Fusarium spp. są: w okolicach Grabowa - odmiana Subito, a w okolicach Taraskowa - odmiana Pizarro.

3. Z grzybów rodzaju Fusarium zasiedlających ziarno pszenżyta ozimego izolowano głównie $F$. poae i $F$. avenaceum.

4. Dominującym grzybem zasiedlającym ziarno pszenżyta ozimego był A. alternata. Licznie izolowano również E. nigrum.

5. Stwierdzono, że istnieje korelacja pomiędzy Fusarium spp., A. alternata i E. nigrum zasiedlającymi ziarno pszenżyta ozimego. 


\section{Literatura / References}

Arseniuk E., Oleksiak T. 2002. Production and breeding of cereals in Poland. Proceedings of the 5th International Triticale Symposium, Radzików, Poland, 30 June-5 July, 2002: 11-20.

Bateman G.L., Gutteridge R.J., Gherbawy Y., Thomsett M.A., Nicholson P. 2007. Infection of stem bases and grains of winter wheat by Fusarium culmorum and F. graminearum and effects of tillage method and maize-stalk residues. Plant Pathology 56 (4): $604-615$. DOI: $10.1111 / j .1365-3059.2007 .01577 . x$

Bisht V., Singh B.P., Arora N., Gaur S.N., Sridhara S. 2002. Antigenic and allergenic cross-reactivity of Epicoccum nigrum with other fungi. Annals of Allergy, Asthma \& Immunology 89 (3): 285-291. DOI: 10.1016/S1081-1206(10)61956-4

Comeau A., Langevin F., Savard M.E., Gilbert J., Dion Y., Rioux S., Martin S.A., Haber S., Voldeng H., Fedak G., Somers D., Eudes F. 2008. Improving Fusarium head blight resistance in bread wheat and triticale for Canadian needs. Cereal Research Communications 36 (6): 91-92.

Flannigan B., Samson R.A., Miller J.D. (red.). 2011. Microorganisms in home and indoor work environments: diversity, health impacts, investigation and control (2nd ed.). Boca Raton, FL, CRC Press, 529 ss.

Góral T. 2009. Odporność odmian pszenżyta ozimego na fuzariozę kłosów powodowaną przez grzyb Fusarium culmorum. [Resistance of winter triticale cultivars to Fusarium head blight caused by Fusarium culmorum]. Biuletyn Instytutu Hodowli i Aklimatyzacji Roślin 254: 41-50.

Góral T., Ochodzki P. 2006. Resistance of Polish winter triticale cultivars to Fusarium head blight and accumulation of Fusarium-myctoxins in grain. Proceedings of the 6th International Triticale Symposium, Stellenbosch, South Africa, September 3-7, 2002: $140-143$.

Góral T., Wiśniewska H., Ochodzki P., Walentyn-Góral D. 2016. Higher Fusarium toxin accumulation in grain of winter triticale lines inoculated with Fusarium culmorum as compared with wheat. Toxins 8 (10): 301. DOI: 10.3390/toxins8100301

Lenc L. 2015. Fusarium head blight (FHB) and Fusarium populations in grain of winter wheat grown in different cultivation systems. Journal of Plant Protection Research 55 (1): 94-109. DOI: 10.1515/jppr-2015-0013

Łączyński A. (red). 2019. Użytkowanie gruntów i powierzchnia zasiewów w 2018 r. GUS, Departament Rolnictwa, Warszawa, s. 74.

Miedaner T., Reinbrecht C., Lauber U., Schollenberger M., Geiger H.H. 2001. Effects of genotype and genotype-environment interaction on deoxynivalenol accumulation and resistance to Fusarium head blight in rye, triticale, and wheat. Plant Breeding 120 (2): $97-105$. DOI: 10.1046/j.1439-0523.2001.00580.x

Parry D.W., Nicholson P. 1996. Development of a PCR assay to detect Fusarium poae in wheat. Plant Pathology 45 (2): $383-391$.

Prodi A., Tonti S., Nipoti P., Pancaldi D., Pisi A. 2009. Identification of deoxynivalenol and nivalenol producing chemotypes of Fusarium graminearum isolates from durum wheat in a restricted area of Northern Italy. Journal of Plant Pathology 91 (3): $727-731$.

Ramires F.A., Masiello M., Somma S., Villani A., Susca A., Logrieco A.F., Luz C., Meca G., Moretti A. 2018. Phylogeny and mycotoxin characterization of Alternaria species isolated from wheat grown in Tuscany, Italy. Toxins 10 (11): 472. DOI: 10.3390/ toxins 10110472

Sadowski Cz., Lenc L., Kuś J. 2010. Fusarium head blight and Fusarium spp. on grain of winter wheat, a mixture of cultivars and spelt grown in organic system. [Fuzarioza kłosów i grzyby rodzaju Fusarium zasiedlające ziarno pszenicy ozimej, mieszaniny odmian i pszenicy orkisz uprawianych w systemie ekologicznym]. Journal of Research and Applications in Agricultural Engineering 55 (4): 79-83.

Veitch R.S., Caldwell C.D., Martin R.A., Lada R., Salmon D., Anderson D.M., MacDonald D. 2008. Susceptibility of winter and spring triticales to Fusarium head blight and deoxynivalenol accumulation. Canadian Journal of Plant Science 88 (4): 783-788. DOI: 10.4141/ CJPS07085

Wiśniewska H., Góral T., Ochodzki P., Walentyn-Góral D., Kwiatek M., Majka M., Grzeszczak I., Belter J., Banaszak Z., Pojmaj M., Kurleto D., Konieczny M., Budzianowski G., Cicha A., Paizert K., Woś H. 2014. Odporność rodów hodowlanych pszenżyta ozimego na fuzariozę kłosów. [Resistance of winter triticale breeding lines to Fusarium head blight]. Biuletyn Instytutu Hodowli i Aklimatyzacji Roślin 271: 29-43. 